\title{
Tribute to Dr. Christopher Gunadasa Uragoda
}

MBBS (Ceylon), MD (Ceylon), Hon DSc (Colombo)

Fellow of the Ceylon College of Physicians, National Academy of Sciences of Sri Lanka, Faculty of Occupational Medicine of the Royal College of Physicians, London, and American College of Chest Physicians

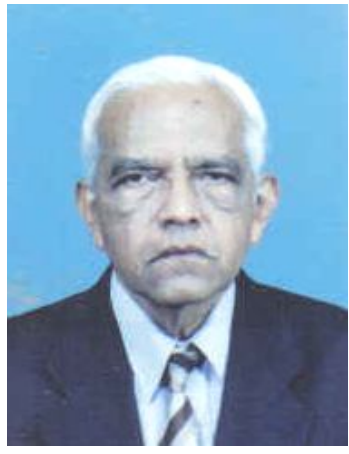

By any reckoning Dr Christopher Gunadasa Uragoda - "Chris" to all his colleagues, friends and everyone else who knew him - is the undisputed doyen of medical authorship, medical editorship, medical history, chest medicine (with particular emphasis on occupational lung disease), and original medical research in Sri Lanka. His research work extended over a period of 30 years (from 1967 to 1997), and the prolific output of 80 scientific papers in recognised journals, is testimony to his diligence and devotion to scientific investigation. His forte was undoubtedly clinical research, which was done, let it be noted, at a time when few sophisticated laboratory tests, imaging techniques and respiratory function tests were available in our country. His original papers exemplify the classical prerequisites for clinical research: astute powers of trained observation, insatiable curiosity to seek answers to why? and how?, and the unrelenting pursuit of the scientific basis for his observations.

Uragoda's research findings on the pulmonary consequences of occupational exposure to tea, cinnamon, kapok, coir, sulphur dioxide, graphite, chilli, silk, coffee and paddy were the first of their kind in the world. His study on workers at an ilmenite extracting factory in a remote jungle is another first. Ilmenite dust $\left(\mathrm{Fe} \mathrm{TiO}_{2}\right)$ was found to be inert, and this paper has been extensively and repeatedly quoted in subsequent papers advocating titanium in various implants.

Another all-time classic was his observation that patients being treated in hospital for tuberculosis developed at regular intervals a set of symptoms that included headache, palpitations, flushing, urticaria and diarrhoea. It was soon observed that these symptoms occurred only on one particular day of the week (Why?), that some patients avoided these symptoms by avoiding a particular dish (What?), and that only patients receiving one particular antituberculosis medicine (What? Why only that? And why only after partaking of this dish?) got these symptoms. And so to the link with three varieties of fish skipjack, bonito and tuna - and inhibition of histaminases. This is a marvel of systematic observation, deduction, hypothesis generation and meticulously testing that hypothesis - and an astounding example of single-minded commitment to the primary research question.

Graphite pneumoconiosis is yet another example of Uragoda's pioneering research on occupational pulmonology; and the first ever survey of lung disease in the graphite industry was the outcome of original research done by him along with two colleagues.

Uragoda's original papers have been published in recognised peer-reviewed journals such as, for example, British Journal of Industrial Medicine, Thorax, Journal of Tropical Medicine and Hygiene, Ceylon Medical Journal, Medical Journal of Australia, and American Journal of Industrial Medicine.

Uragoda's writing is by no means confined to original medical research; they extended to books on history, bibliography, antiquary and wildlife. His landmark centenary publications, A History of Medicine in Sri Lanka (1987), and Wildife Conservation in Sri Lanka (1904) are extremely valuable perennial primary sources. Traditions of Sri Lanka, a Selection with a Scientific Background (2008) and Traditional Appliances and Practices of Sri Lanka (2009) bear witness to his abiding interest in the piquant and emotive charm of antiquary. And the four comprehensive bibliographies he has coauthored with Kamalika Pieris and G P S H de Silva will retain their reference value for many decades to come.

Dr Uragoda has won many awards, including the Guinness Award in 1980, Peter Pillai Award in 1981, and the Deshabandu President's Award in 1994. He was awarded the DSc by the University of Colombo, and conferred the Membership (through distinction) of the Faculty of Occupational Medicine, London - both very rare achievements for a Sri Lankan.

He has held the offices of elected President of the Sri Lanka Medical Council, Sri Lanka Medical Association, Ceylon College of Physicians, Kandy Society of Medicine, and The Royal Asiatic Society of Sri Lanka. He has been editor of the Ceylon Medical Journal for 20 years, Journal of the Ceylon College of Physicians for 5 years, and the National Academy of Sciences of Sri Lanka for 4 years. 
A mere recital of Uragoda's lengthy list of achievements, in multiple specialities such as they are, admittedly impressive and extensive in themselves, scarcely do justice either to his exemplary character or his polymath persona.

A self-effacing and upretentions nature are the distinctive features of his academic and professional personality. All the prestigious posts he held came to him by way of election by peers, and the numerous distinguished awards he received were the richly deserved outcomes of his work. Integrity and ethical propriety permeate his long and illustrious career, and illumine the solid scientific foundations of his research.

His advice to others is replete with wisdom, his praise (when appropriate!) is fulsome and unreserved, his

C Goonaratna, Emeritus Editor, Ceylon Medical Journal. E-mail: si7np5e@gmail.com pleasure at the success of those whom he admires is genuine and transparent, and his criticisms (when deserved) are cogent, engaging and analytical. He is a most agreeable conversationalist and a superb raconteur, with a veritable storehouse of experiences and lively anecdotes.

Christopher Gunadasa Uragoda has adorned the professional and academic landscape of medical science in our motherland during our lifetime, and embellished the laurels he has been deservedly awarded, lightly and without affectation.

I wish for him many more years of good health and more of the work he loves to do. I am privileged to write this tribute to Chris. 